\title{
Isolated Intracardiac Metastasis: The First Sign of Hepatocellular Carcinoma
}

\author{
Anusca Paixão Rita Silva Natália Lopes Sónia Carvalho Paulo Carrola \\ José Presa Ramos
}

Serviço de Medicina Interna, Hospital de São Pedro, Vila Real, Portugal

\section{Keywords}

Acute heart failure - Isolated cardiac metastasis .

Hepatocellular carcinoma

\begin{abstract}
Metastatic hepatocellular carcinoma (HCC) to the right atrium without invasion of the inferior vena cava is a very rare and difficult diagnosis, especially when the primary tumour is yet to be known. A 68-year-old man with symptoms of heart failure was admitted to the emergency department; his transthoracic echocardiogram showed a mass comprehending almost the totality of the right atrium, obliterating its entrance nearly completely and impeding the normal auricular-ventricular flux, described as a possible auricular myxoma. The patient was promptly transferred to cardiothoracic surgery and submitted to an urgent surgery to completely remove the mass, which was macroscopically described as suspected of malignancy. Further investigation demonstrated a single nodule in the liver with malignant imaging characteristics, and the histology confirmed the diagnosis of metastatic HCC of the right atrium, without metastatic disease elsewhere. He was then submitted to radiofrequency ablation and medicated with sorafenib. The disease progressed slowly but subsequently involved the inferior vena cava and portal vein, culminating in his death 4 years and 3 months after the diagnosis. Although the prognosis for metastatic HCC may be poor, especially with intracavitary
\end{abstract}

heart metastasis, this case shows that an aggressive initial approach with surgical metastasectomy may prolong the median survival of the patients.

(c) 2021 Sociedade Portuguesa de Gastrenterologia Published by S. Karger AG, Basel

\section{Metástase intracardíaca isolada: 0 primeiro sinal de carcinoma hepatocelular}

\section{Palavras Chave}

Insuficiência cardíaca aguda · Metástase cardíaca isolada Carcinoma hepatocelular

\section{Resumo}

A metastização intracardíaca de um carcinoma hepatocelular sem invasão da veia cava inferior é um diagnóstico raro e difícil, especialmente quando o tumor primário não foi ainda diagnosticado. Um homem de 68 anos foi admitido no Serviço de Urgência com sintomas de insuficiência cardíaca aguda. O ecocardiograma transtorácico mostrou uma massa que atingia quase a totalidade da aurícula direita, praticamente obliterando a sua entrada e impedindo o normal fluxo auriculoventricular, descrita como possível mixoma auricular. $\mathrm{O}$ doente foi imediatamente transferido para cirurgia cardiotorácica e submetido a cirurgia urgente para resseção da massa que foi mac- karger@karger.com www.karger.com/pjg

Karger $\stackrel{\text { ' }}{5}$

GOPEN ACCESS (c) 2021 Sociedade Portuguesa de Gastrenterologia Published by S. Karger AG, Basel

This is an Open Access article licensed under the Creative Commons Attribution-NonCommercial-4.0 International License (CC BY-NC) (http://www.karger.com/Services/OpenAccessLicense), applicable to the online version of the article only. Usage and distribution for commercial purposes requires written permission.
Correspondence to:

Anusca Paixão, aksuna16@gmail.com 
roscopicamente descrita como suspeita de malignidade. A investigação subsequente demonstrou um nódulo isolado hepático com características imagiológicas de malignidade, e a histologia da massa auricular confirmou o diagnóstico de metastização auricular de carcinoma hepatocelular. O doente foi posteriormente submetido a ablação por radiofrequência e medicado com sorafenib, com progressão lenta mas contínua da doença e subsequente atingimento metastático da veia cava inferior e veia porta, que culminou na sua morte quatro anos e três meses após o diagnóstico. Apesar do prognóstico ser reservado para o carcinoma hepatocelular metastático, especialmente na presença de metástases intracardíacas, este caso clínico mostra que uma abordagem inicial mais agressiva com metastasectomia pode prolongar a sobrevida média dos doentes.

(C) 2021 Sociedade Portuguesa de Gastrenterologia Publicado por S. Karger AG, Basel

\section{Introduction}

Hepatocellular carcinoma (HCC) is the number one malignancy of the liver, the fifth most common tumour worldwide and the third most common cause of death related to cancer [1]. Chronic liver disease and cirrhosis remain the most important risk factors to develop HCC [2]. Most cases of HCC are diagnosed at an advanced stage, and the tumour spreads most frequently to the lungs, peritoneum, adrenal glands, and bones [3]. Intracavitary cardiac metastases are very unusual in HCC, and when they occur, they usually invade the heart as an extension of intravascular metastasis or infiltration through nearby organs [4]. The prognosis is poor for metastatic HCC, but surgical treatment, especially in symptomatic intracardiac metastasis, may improve not only quality of life but also survival [5].

Herein, we present a case of an isolated metastasis of HCC to the heart, in which symptoms led to the diagnosis of the primary neoplasm. Informed consent was obtained from the patient's relatives.

\section{Case Report/Case Presentation}

We present the case of a 68 -year-old male with reported history of systemic arterial hypertension, hypercholesterolemia, benign prostatic hyperplasia, and alcoholic liver cirrhosis of ChildPugh A with no recent follow-up, medicated with lisinopril, simvastatin and dutasteride + tamsulosin. He was a non-smoker but had sustained alcoholic habits, had no known allergies and his

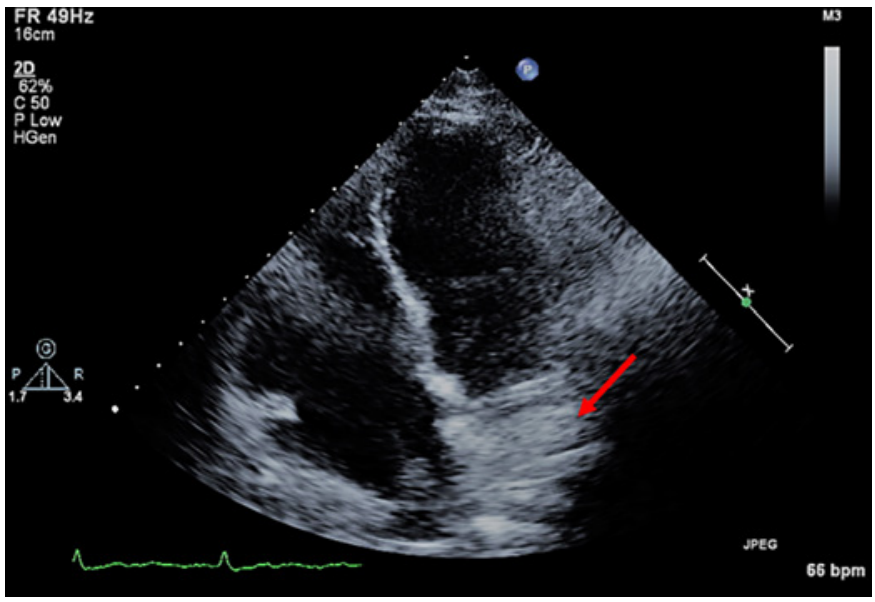

Fig. 1. Echocardiography showing right atrial mass (red arrow).

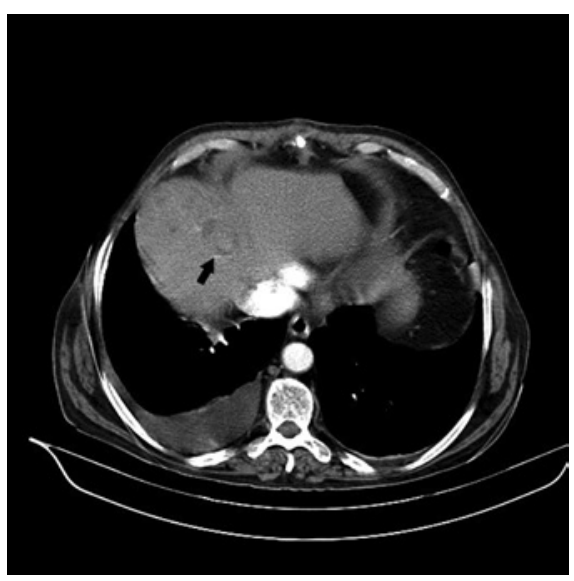

Fig. 2. Initial CT scan showing 3.5-cm nodule in the IV segment of the liver (black arrow).

family history was irrelevant. He presented to the emergency department with dyspnoea, orthopnoea and lower limbs oedema of 4 months duration and acute aggravation. He was initially diagnosed with acute heart failure and medicated with furosemide. A transthoracic echocardiogram was scheduled to evaluate the cardiac function, which showed a mass comprehending almost the totality of the right atrium, obliterating its entrance nearly completely and impeding the normal auricular-ventricular flux, described as an auricular myxoma (Fig. 1). The patient was promptly transferred to cardiothoracic surgery and submitted to an urgent intervention to remove the mass completely. Macroscopically, it was not compatible with a myxoma, but rather with malignant metastatic tissue, which was why the patient was then transferred to internal medicine to investigate the location of the primary tumour, while waiting for the histological results. A multiphasic contrast-enhanced computed tomography (CT) scan evidenced a 3.5$\mathrm{cm}$ nodule in the IV segment of the liver, with arterial enhancement and subsequent washout on the portal phase, with no evidence of malignant disease elsewhere (Fig. 2). 


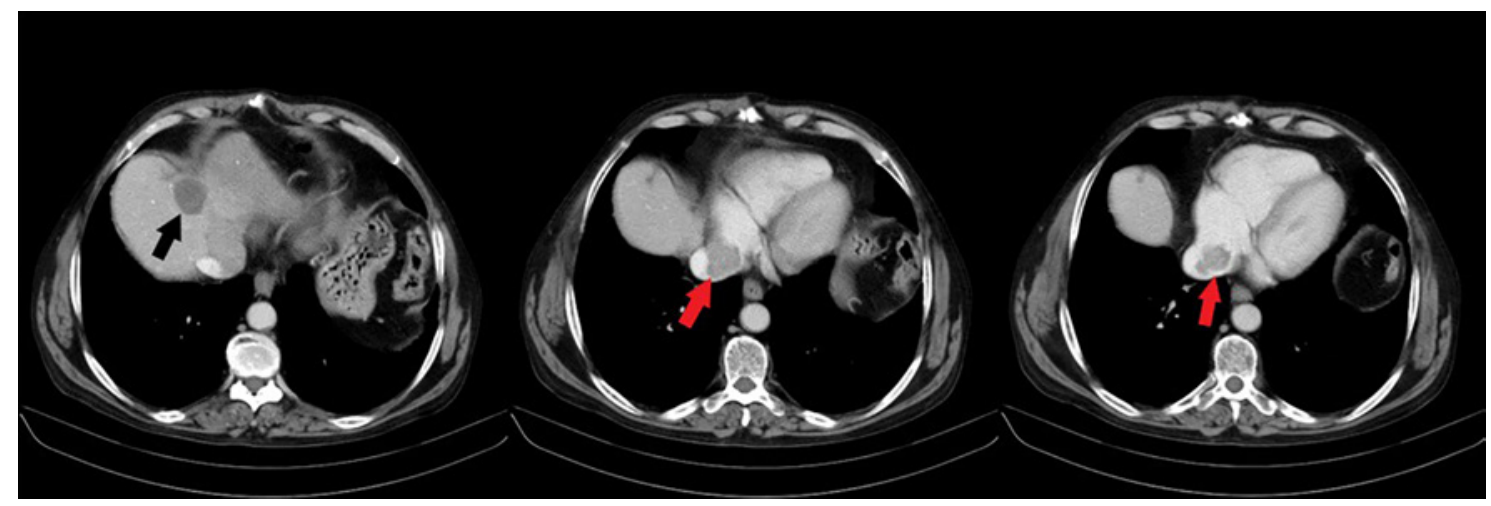

Fig. 3. CT scan showing invasion of the inferior vena cava by the tumoral mass with extension to the right atrium (red arrows) and an extensive lesion of the liver comprehending the IV and II segments (black arrow).

The diagnosis of HCC with single heart metastasis was established with the aid of the histopathological result of the atrial mass, which showed an epithelioid neoplasm of solid and trabecular pattern with areas of necrosis, constituted of bulky cells of granular eosinophilic cytoplasm with round nuclei and with a prominent eosinophilic nucleolus. The immunohistochemical study showed diffuse and intense immunoreactivity of the neoplastic cells for HepPar-1, in the absence of expression of S100, vimentin, CD34, factor VIII, alpha fetoprotein and AE1AE3, compatible with metastatic hepatocarcinoma.

Considering that the single metastasis had been removed with no evidence of portal invasion or any other metastatic disease, it was decided that the patient should undergo radiofrequency ablation (RFA) followed by sorafenib $400 \mathrm{mg}$ /day. During this period, the patient stopped consuming alcohol, having been medicated with oxazepam and baclofen without relapsing. One month after the RFA, the CT scan showed signs of complete response. Nevertheless, 1 year later, the patient recurred with a new liver lesion of $14 \mathrm{~mm}$ in the IV segment and was again submitted to RFA with complete response. One year later, on a control CT scan, the patient presented an invasion of the inferior vena cava by a tumoral mass with extension to the right atrium and an extensive lesion of the liver comprehending the IV and II segments (Fig. 3), after which referral to palliative care was decided.

He maintained sorafenib for another 2 years with progressive vascular invasion, that is, with portal vein thrombosis and extension to the medial and right hepatic veins. Progressive hepatic encephalopathy and increasing oedema led to his hospitalization and death. The survival time of this patient, from the date of diagnosis, was 4 years and 3 months.

\section{Discussion/Conclusion}

This unique case shows the development of single metastatic disease of the heart in a patient with previous alcoholic liver cirrhosis who missed the follow-up. Although HCC may metastasize to various extrahepatic organs, metastases with cardiac involvement are rare [6], generally occurring in advanced stages of the disease with invasion of the portal vein and evidence of portal thrombosis [4], which were both absent at diagnosis in this particular case report.

The prognosis of HCC with cardiac involvement is poor, and the median survival time at diagnosis is 102 days [7]. Our patient survived for 4 years and 3 months, most of them with good quality of life and autonomy, with a total of only 33 days of hospitalization in that period. This may be due to the initial and early surgical approach to metastatic disease.

Although we were initially optimistic about the patient's evolution after the initial removal of the atrial mass and RAF of the first liver injury, the recurrence of HCC and metastatic disease in the inferior vena cava may indicate that haematogenous spread of the previous disease to the atrial implant had occurred, even in the absence of macroscopic invasion of the portal vein at the time of diagnosis.

\section{Statement of Ethics}

This case report was written in accordance with the World Medical Association Declaration of Helsinki. Informed consent was obtained from the patient's relatives.

\section{Conflict of Interest Statement}

The authors have no conflicts of interest to declare. 


\section{Funding Sources}

No funding or sponsors were used in the preparation of this manuscript.

\section{References}

1 Raza A, Sood GK. Hepatocellular carcinoma review: current treatment, and evidencebased medicine. World J Gastroenterol. 2014 Apr;20(15):4115-27.

2 Balogh J, Victor D 3rd, Asham EH, Gordon Burroughs S, Boktour M, Saharia A, et al. Hepatocellular carcinoma: a review. J Hepatocell Carcinoma. 2016;3:4153.

3 Masci G, Magagnoli M, Grimaldi A, Covini G, Carnaghi C, Rimassa L, et al. Me-

\section{Author Contributions}

Anusca Paixão: First author. Interpreted and organized the data. Wrote the case report. Rita Silva: Conception, organization and design of the work/case report. Natália Lopes: Revised the work for intellectual content. Sónia Carvalho: Revised the work for intellectual content. Paulo Carrola: Final approval of the version to be published. José Presa Ramos: Revised the work for intellectual content. tastasis of hepatocellular carcinoma to the heart: a case report and review of the literature. Tumori. 2004 May-Jun; 90(3):345-7.

4 Tastekin E, Usta U, Ege T, Kazindir G, Kutlu AK. Cardiac metastasis of hepatocellular carcinoma in a young non-cirrhotic patient, to the left ventricle. Ann Hepatol. 2012 MayJun;11(3):392-4.

5 Kim SB, Shin YC, Kwon SU. Isolated metastasis of hepatocellular carcinoma in the right ventricle: A case report. Medicine (Baltimore). 2016 Dec;95(51):e5544.

6 Fukuoka K, Masachika E, Honda M, Tsukamoto Y, Nakano T. Isolated metastases of hepatocellular carcinoma in the left atrium, unresponsive to treatment with sorafenib. Mol Clin Oncol. 2015 Mar;3(2):397-9.

7 Albackr HB. A large Right atrial mass in a patient with hepatocellular carcinoma: case report and literature review. J Saudi Heart Assoc. 2014 Jul;26(3):174-8. 